Egypt. J. of Nutrition and Health Vol. 16 No. 1 January (2021)

\title{
Study the factors associated with overweight and obese in early adolescent girls in urban and rural environment
}

\author{
Bassem,A.Zwain \\ Clinical Nutrition Fellowship ,Cairo University Hospitals
}

\begin{abstract}
Obesity is a complex problem resulting from an imbalance between energy intake and energy expenditure with genetic, metabolic and behavioral components. Obesity is defined as an excessive fat accumulation in the body that presents a risk to health. The present work was designed to study the prevalence of overweight/obesity in early adolescents' girls, aged 10 to 12 years, from rural and urban regions and the risk factors related to obesity as eating habits, and physical activities. The sample was 100 adolescents girls, aged between 10 to 12 years from rural and urban environments. The used questionnaires included eating habits and physical activity, focusing on the number of daily meals, meal composition, and lifestyle habits. An anthropometric assessment was performed, including weight, height, waist circumference, percentage of lean mass and body fat (BF).In the rural environment, the obesity rate was $10 \%$ either overweight or obese; being less than the urban environment. Living in a rural environment was not an independent predictor of being overweight or obesity, $p=0.456$, or for increased percentage of body fat, $p=0.285$. In contrast, being 12 years old, eating high-calorie foods four times a week or less, and having at least one obese parent were predictors of being overweight or obesity. Being 12 years old was also a predictor of gaining moderate to high body fat. Adolescents' residence in a rural or urban environment affects the occurrence of being overweight, obesity or high body fat. Paternal obesity was an important predictor of obesity in adolescents. Obese fathers tended to serve higher calorie meals to their adolescents.
\end{abstract}

Keywords: Rural and urban- anthropometric assessment- lifestyle habits- obese early adolescents

\section{Introduction}

Obesity was traditionally defined as an increase in body weight greater than 20 percent of an individual's ideal body weight and also it is defined as "an excessive deposit of body fat (BF) which may result in adverse metabolic consequences, that impair short and long term physical health and create psychological disorders. The weight is affected by certain factors, such as age, height, gender, genetics and family environment, as well as being related to cultural, eating, and sedentary habits. Today the definitions of overweight and obesity are based primarily on measures of weight and height. These measures are used to calculate the body mass index (BMI). The World Health Organization (WHO) Regional Office for the Western Pacific Region has suggested body mass index (BMI) standards that differ from those used in Europe and North America: Normal, 18.5-22.9 kg/m2;

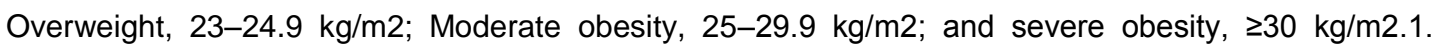
There is an association between obesity and dyslipidemia, high blood pressure, type 2 diabetes, orthopedic disorders, hepatic steatosis and psychological disorders. According to the WHO, the 


\section{Bassem,A.Zwain}

incidence of childhood obesity in Europe has risen from $10 \%$ to $40 \%$ in the last decade, and to over 30\% in Africa (WHO, 1998 and Lobstein et al., 2004 ).

There are various methods available for assessing body composition as necropsy (highly sensitive), extrapolation, anthropometric parameters, bioelectrical impedance (BIO), densitometry (which measures total $\mathrm{BF}$ and its distribution), lean and bone mass, computerized axial tomography, and magnetic resonance imaging. Obesity is a multifactorial etiological condition which is associated with metabolic, genetic, nutritional, socioeconomic, cultural, psychological, lifestyle factors and laboratory workup (Ohly et al., 2013).

The management of obesity is centered on lifestyle changes, rarely requiring pharmacological or surgical interventions. It is important to follow a set of guidelines, which require a joint effort involving the patient, family, school, healthcare centers, and local institutions, with the latter providing sports and leisure activities. Behavioral therapy aims to change family lifestyle habits(Levin, 2014). To prevent obesity and related diseases, health education, urban eating habits, and physical activity from kindergarten to adulthood should be recommended(Jolliffe and Janssen, 2018).

There are few studies available that compare adolescent obesity in rural and urban environments(Troiano and Flegal, 2019), The objectives of this study are to determine the prevalence of overweight and obesity in adolescent females aged 10 to 12 years, from rural and urban environment and to identify the risk factors related to the obesity as eating habits, and physical exercise.

\section{Volunteers\&Methods}

\section{Research Design}

A retrospective study was used. This design according to the available literature is considered to be appropriate as it allows the researcher to assess the dependent variable in the present (obesity or over weight) and then links these factors occurring on the adolescence, with the psychological and physical health.

\section{Setting of the study}

This study was conducted in two public schools in urban and rural regions living in Ashmoun,Menoufia. Sampling

The total sample size was 100 girls between the ages of 10 and 12 years. They were obtained by systematic random sample.

\section{Period of study}

The present study started in March 2019 and ended in October2019.

\section{Methods}

\section{The questionnaires}

Three forms of questionnaires were used:

- The first one was for socioeconomic data for parents including the educational level.

- The second one for disease history and an thropometric measurements of the girls students.

- The third one for the food habits, it included food likes, dislikes, all the characteristics related to the adolescents meals, and the possible suggestion of the target for improvements meals served 


\title{
Egypt. J. of Nutrition and Health Vol. 16 No. 1 January (2021)
}

\author{
Anthropometric Measurements \\ Weight and height were measured while girls were in light clothing and no shoes. Body mass index \\ (BMI) was calculated as Body Weight $(\mathrm{Kg}) /$ Height $(\mathrm{m})^{2}$. (Passmore and Eastwood, 1986).Waist \\ circumference and body fat were measured according to Fernandez et al.(2004). Lean mass and \\ water weight determined by Frisancho, (1990) and Binns\&Ariza, (2004).

\section{Laboratory investigation} \\ Hemoglobin was determined according to Makarem, 1974. Hematocrit and White blood cells were \\ determined according to Dacie and Lewis, (1998). Serum calcium and phosphorus assessed by \\ atomic absorption spectrophotometer (Fraser et al., 1986), Serum ALP was determined according to \\ (International Federation of Clinical Chemistry methods., 1983).I
}

\section{Assessment of Nutrient intake}

Food intake was recorded on four consecutive days (24 hour recall). Energy and nutrients intake were calculated by using a computer program (FIAS,1996) based on the food composition table of the National Institutes of Nutrition, Egypt. Results were compared with the Recommended Dietary Allowance and Recommended Daily Intake( 1989). The questionnaire for adolescent's mothers was used to collect data about some dietary habits for their adolescents to confirm that obtained from the girls.

\section{Statistical analysis}

Statistical analysis was conducted according to Snedecor and Cochran (1972). Pearson's correlation coefficients were calculated between intake of nutrients and dietary variables or various health indices, such as anthropometric and blood chemical analysis data. Two -side P-values $<0.05$ were considered significant.

\section{Results and Discussion}

\section{Anthropometric measurement for Urban and Rural adolescents}

From data in table (1), It could be noticed that the mean value of weight for the Urban adolescents was significantly higher than the Rural adolescents $(57.2 \mathrm{Vs} 53.7) \mathrm{kg}$, and when compared with the standard (Passmore and Eastwood, 1986) the urban adolescents satisfied $142.5 \%$ and the rural adolescents satisfied $132.5 \%$ with very high significant level. As for height, it could be observed that the urban adolescents height was $92.8 \%$ of DRI but Rural adolescents height was $94.4 \%$ of DRI. Body mass index the mean value was (35.4 and 32.16) for urban and rural adolescents respectively, denoting high significant difference $(P<0.001)$.

There is no differences regarding the standard WC values, $p=0.456$. Nevertheless, body fat was expressed more in both groups, with $74 \%$ in the urban environment vs. $80 \%$ in the rural environment. With regard to water weight, there is no statistically significant differences in target ( $p=0.553$ ). Regarding target lean body mass Frisancho, (1990) and Binns\&Ariza, (2004) adolescents from Rural and Urban environments had high lean body masses $p<0.001$ (Table 2). 
Table (1):

Mean \pm SD of weights, heights and body mass index.

\begin{tabular}{c|c|c|c|c|c|c}
\hline Variable & $\begin{array}{c}\text { Urban group } \\
\text { Mean } \pm \text { SD }\end{array}$ & $\begin{array}{c}\text { DRl\% } \\
\text { Urban }\end{array}$ & $\begin{array}{c}\text { Rural group } \\
\text { Mean } \pm S D\end{array}$ & DRI\% Rural & DRI & T-test \\
\hline Weight & $57.2 \pm 11.53$ & $142.5 \%$ & $53.7 \pm 10.99$ & $132.5 \%$ & $40 \mathrm{~kg}$ & $7.87^{\star * *}$ \\
\hline Height & $127.2 \pm 7.48$ & $92.8 \%$ & $129.3 \pm 7.81$ & $94.4 \%$ & $137 \mathrm{~cm}$ & $5.53^{*}$ \\
\hline BMI & $35.4 \pm 1.32$ & - & $32.16 \pm 2.33$ & - & - & $7.32^{\star * *}$ \\
\hline
\end{tabular}

Table (2):

Frequency and percent waist circumference,body fat, water weight and lean mass of Rural and Urban groups

\begin{tabular}{|c|c|c|c|c|c|c|}
\hline \multirow{2}{*}{\multicolumn{2}{|c|}{ Variable }} & \multicolumn{2}{|c|}{ Urban group } & \multicolumn{2}{|c|}{ Rural group } & \multirow{2}{*}{$\mathrm{P}$} \\
\hline & & \multirow{2}{*}{$\frac{\text { Frequency }}{1}$} & \multirow{2}{*}{$\frac{\text { Percent }}{2}$} & \multirow{2}{*}{$\begin{array}{c}\text { Frequency } \\
0\end{array}$} & \multirow{2}{*}{$\begin{array}{c}\text { Percent } \\
0\end{array}$} & \\
\hline \multirow{3}{*}{ Waist circumference } & Normal & & & & & \multirow{3}{*}{0.456} \\
\hline & High & 19 & 38 & 33 & 66 & \\
\hline & Obese & 30 & 60 & 17 & 34 & \\
\hline \multirow{3}{*}{ Body fat } & Normal & 1 & 2 & 0 & 0 & \multirow{3}{*}{0.285} \\
\hline & Moderate & 12 & 24 & 10 & 20 & \\
\hline & High & 37 & 74 & 40 & 80 & \\
\hline \multirow{3}{*}{ Water Weight } & Low & 0 & 0 & 0 & 0 & \multirow{3}{*}{0.553} \\
\hline & Normal & 33 & 66 & 35 & 70 & \\
\hline & High & 17 & 34 & 15 & 30 & \\
\hline \multirow{3}{*}{ Lean Mass } & Low & 0 & 0 & 0 & 0 & \multirow{3}{*}{0.001} \\
\hline & Normal & 2 & 4 & 1 & 2 & \\
\hline & High & 48 & 96 & 49 & 98 & \\
\hline
\end{tabular}

Laboratory investigation for Urban and Rural adolescents (Table 3)

The hemoglobin and hematocrit levels for the urban adolescents were higher than the rural adolescents with mean values (11.75 and 10.33)for the Urban and Rural group respectively, $(P<$ 0.001 ), whereas white blood cells in the urban adolescents were lower than the rural adolescents with mean values (5.11 and 6.89), $(P<0.001)$.

As well the mean values of $\mathrm{Ca++}$ ionized, ca total, serum phosphorus in urban group were higher than the mean values for the rural group.

The mean value of alkaline phosphatase for the Urban adolescents was 455.96 whereas the Rural group was 1000.34 which were higher than the urban group. As shown in table (9) rural adolescent's mothers used to give their adolescents tea and carbonated beverage after or before meal which decreased iron and calcium malabsorption causing anemia and rickets which is reflected into lower means of HB, hematocrit and calcium levels of rural adolescents compared with means of urban adolescents. 


\section{Egypt. J. of Nutrition and Health Vol. 16 No. 1 January (2021)}

Table (3):

Mean \pm SD of laboratory parameters of the adolescents girls .

\begin{tabular}{l|c|c|c|c}
\hline Variable & $\begin{array}{c}\text { Urban group } \\
\text { Mean } \pm \text { SD }\end{array}$ & $\begin{array}{c}\text { Rural group } \\
\text { Mean } \pm S D\end{array}$ & Normal value & T-test \\
\hline $\begin{array}{l}\text { HB } \\
\text { Gm \% }\end{array}$ & $11.75 \pm .3 .40$ & $10.33 \pm 1.16$ & $11.5-15.5$ & $8.33^{* * *}$ \\
\hline Hematocrit \% & $35.34 \pm .8 .2$ & $31.01 \pm 3.47$ & $35-45$ & $8.56^{* * *}$ \\
\hline $\begin{array}{l}\text { WBC } \\
\text { thousands }\end{array}$ & $5.11 \pm 0.93$ & $6.89 \pm 2.00$ & $4.3-13.5$ & $5.58^{* * *}$ \\
\hline $\begin{array}{l}\text { RBC } \\
\text { (million) }\end{array}$ & $4.68 \pm 0.21$ & $4.47 \pm 2.1$ & $4-5.2$ & $3.48^{* *}$ \\
\hline $\begin{array}{l}\text { Ca } \\
\text { Mg /d } \text { ionized }\end{array}$ & $4.87 \pm 0.15$ & $3.55 \pm 1.04$ & $4.6-5.3$ & $8.74^{* * *}$ \\
\hline $\begin{array}{l}\text { Ca total } \\
\text { Mg/dl }\end{array}$ & $9.65 \pm 0.45$ & $8.17 \pm 0.91$ & $8.7-10.7$ & $10.13^{* * *}$ \\
\hline $\begin{array}{l}\text { Alkaline phosphatase } \\
\text { Serum phosphorus }\end{array}$ & $455.96 \pm 77.31$ & $1000.34 \pm 42.48$ & Up to 800 & $8.94^{* * *}$ \\
\hline
\end{tabular}

\section{Assessment of Nutrient intake for Urban and Rural adolescents}

From table (4) it could be noticed that calories intake by urban adolescents were higher than calories intake by rural adolescents which were higher than DRI (108.1\% and $105.7 \%$ of DRI).The percentage of protein intake was very high for urban adolescents compared with the rural adolescents. Total protein was $199.6 \%$ of recommended allowance. For fat intake, there was very high significant differences between urban and rural adolescents $(P<0.001)$. Carbohydrate and water intake of urban adolescents were higher than the Rural group with very high significant differences. The mean value of cholesterol was (184.8 and 42.4) for urban and rural adolescents respectively $(P<0.001)$. In urban adolescents ash content, the mean value was 5.26 in urban diet but it was 3.11 in rural adolescents diet $(\mathrm{P}<0.001)$. Previous study found that Phosphorus and calcium are used in the body to create calcium-phosphate, which is the main component of bone. However, the combination of too much phosphorus with too little calcium in the body can lead to a degeneration of bone mass.

Research suggests a statistically significant inverse relationship between consumption of carbonated beverages and bone mineral density in young girls, which places them at increased risk of suffering fractures in the future (Carmo et al., 2013).34\% of rural adolescents' snacks were carbonate and their calcium intake were $27.2 \%$ of DRI so this explain the finding of rickets among Rural adolescents. High alkaline phosphatase result more than normal range among rural adolescents, serum alkaline phosphatase mean value in the urban healthy adolescents were 455.96, this result is within normal range whereas alkaline phosphatase mean value in the rural of healthy adolescents were 1000.34 is higher than the normal range, Also the mean values of ionized ca++ and serum phosphorus were (3.55 and 4.01) respectively are lower than normal range because of daily intake of phosphorus and $\mathrm{Ca}$ were $74.4 \%$ and $27.2 \%$ respectively of $\mathrm{DRI}$ for Rural adolescents, Alkaline phosphatase, ionized $\mathrm{Ca}++$ and serum phosphorus are the most important tools that define and diagnose rickets.

Serum alkaline phosphatase activity, serum phosphorus, and serum Ca have traditionally been used to screen the metabolic bone disease. Elevated alkaline phosphatase and decreased serum phosphorus correlate with increased risk of rickets (Picciano, 2017).Also, it could be noticed that calories intake by Urban adolescents were $108 \%$ higher than dietary recommended allowance and 


\section{Bassem,A.Zwain}

$105 \%$ in Rural adolescents of DRI, The percentages of protein intake of Urban adolescents was $199.6 \%$ more than Rural adolescents which was $77.48 \%$ compared with DRI with highly significant differences $(\mathrm{P}<0.001)$.

Table (4):

Mean \pm SD of dietary intake by adolescent girls Main characteristic of samples.

\begin{tabular}{|c|c|c|c|c|c|c|c|}
\hline \multicolumn{2}{|c|}{ Nutrients } & Urban Group & $\begin{array}{l}\text { DRI\% } \\
\text { Urban }\end{array}$ & Rural Group & $\begin{array}{l}\text { DRI\% } \\
\text { Rural }\end{array}$ & DRI & t-test \\
\hline \multicolumn{2}{|l|}{ Water } & $\begin{array}{c}1334.60 \pm 79.4 \\
7\end{array}$ & $88.9 \%$ & $\begin{array}{c}1202.32 \pm 72.1 \\
8\end{array}$ & $80.1 \%$ & $\begin{array}{c}150 \\
0\end{array}$ & $8.713^{* * *}$ \\
\hline \multicolumn{2}{|c|}{ Energy (k.cal) } & $\begin{array}{c}1080.70 \pm 302 . \\
43\end{array}$ & $108.1 \%$ & $\begin{array}{c}1057.36 \pm 130 \\
37\end{array}$ & $105.7 \%$ & $\begin{array}{c}100 \\
0\end{array}$ & $8.488^{* \star *}$ \\
\hline \multirow{3}{*}{$\begin{array}{l}\text { Protein } \\
(\mathrm{g} / \mathrm{dl})\end{array}$} & Animal protein (\%) & $35.61 \pm 11.41$ & $214.5 \%$ & $2.47 \pm 3.41$ & $14.8 \%$ & 16.6 & $\underset{* \star}{19.687}$ \\
\hline & $\begin{array}{l}\text { Plant protein } \\
(\%)\end{array}$ & $14.30 \pm 6.05$ & $170.2 \%$ & $16.60 \pm 4.21$ & $197.6 \%$ & 8.4 & $2.212^{*}$ \\
\hline & Total protein & $49.90 \pm 12.11$ & $199.6 \%$ & $19.37 \pm 5.12$ & $77.48 \%$ & 25 & $\underset{* *}{16.425}$ \\
\hline \multirow{3}{*}{$\begin{array}{l}\text { Fat } \\
(\mathrm{g} / \mathrm{d})\end{array}$} & Animal fat (\%) & $19.80 \pm 11.38$ & $178.3 \%$ & $3.67 \pm 3.18$ & $33 \%$ & 11.1 & $9.655^{* \star \star}$ \\
\hline & Plant fat (\%) & $23.46 \pm 12.10$ & $105.7 \%$ & $12.26 \pm 2.92$ & $55.2 \%$ & 22.2 & $6.359^{* * *}$ \\
\hline & Total fat & $43.29 \pm 14.60$ & $130 \%$ & $15.92 \pm 3.97$ & $47.8 \%$ & 33.3 & $\underset{* *}{12.789}$ \\
\hline \multicolumn{2}{|c|}{ Carbohydrate (g/dl) } & $\begin{array}{c}122.873 \pm 49.1 \\
3\end{array}$ & $81.91 \%$ & $209.15 \pm 23.88$ & $139.43 \%$ & 150 & .435 \\
\hline \multicolumn{2}{|c|}{ Fiber $(g / d)$} & $5.87 \pm 3.92$ & $26.7 \%$ & $6.77 \pm 3.05$ & $30.7 \%$ & 22 & 1.284 \\
\hline \multicolumn{2}{|l|}{ Ash } & $5.26 \pm 1.63$ & & $3.11 \pm 1.89$ & & & $6.111^{\star \star \star}$ \\
\hline \multicolumn{2}{|c|}{ Cholesterol (mg/d) } & $184.8 \pm 78.7$ & & $42.4 \pm 35.2$ & & & $11.675^{\star}$ \\
\hline
\end{tabular}

The results of table (5)showed the parents characteristics of the study sample. It could be found that father size (normal, overweight and obese) were 24, 10 and 66\% from total sample respectively for the Urban group, whereas father's size of Rural adolescents were $44 \%$ for the normal and $48 \%$ for the obese respectively from total samples. While, mother's size for the Urban adolescents were $38 \%$ normal, $6 \%$ overweight and $56 \%$ obese size however, Rural adolescents' mother were $16 \%$ normal size, $36 \%$ overweight size and $48 \%$ obese size. In case of the percentage of factor at least one obese parent, it could be observed that $20 \%$ and $80 \%$ for no found and yes answer respectively for rural was detected while in urban, the percentage was 40 and $60 \%$ respectively for the same above factor. Through research in the cases of early adolescents to assess their nutritional status it could be found that more than half of the studied sample had medical and nutritional problems. As shown in the table which was talking about father size and mother size of the Rural and Urban groups found that for father and mother size, obese and normal size for both father and mother among Urban adolescents were higher than Rural adolescents but the opposite for overweight for mother size. 


\section{Egypt. J. of Nutrition and Health Vol. 16 No. 1 January (2021)}

Table (5):

Frequency and percent of father size, mother size and at least one obese parent of the Rural and Urban groups

\begin{tabular}{|c|c|c|c|c|c|}
\hline \multirow{2}{*}{\multicolumn{2}{|c|}{ Variable }} & \multicolumn{2}{|c|}{ Urban } & \multicolumn{2}{|c|}{ Rural } \\
\hline & & Frequency & percent & Frequency & percent \\
\hline \multirow{3}{*}{ Father size } & normal & 12 & $24 \%$ & 22 & $44 \%$ \\
\hline & Overweight & 5 & $10 \%$ & 4 & $8 \%$ \\
\hline & obese & 33 & $66 \%$ & 24 & $48 \%$ \\
\hline \multirow{3}{*}{ Mother Size } & normal & 19 & $38 \%$ & 8 & $16 \%$ \\
\hline & Overweight & 3 & $6 \%$ & 18 & $36 \%$ \\
\hline & obese & 28 & $56 \%$ & 24 & $48 \%$ \\
\hline \multirow{2}{*}{ At least one obese parent } & No & 20 & $40 \%$ & 10 & $20 \%$ \\
\hline & Yes & 30 & $60 \%$ & 40 & $80 \%$ \\
\hline
\end{tabular}

The socio-economic data of Rural and Urban early adolescents

Data in table (6 and 7) recorded that the highest percentage for father and mother education was illiterate fathers for Rural adolescents and secondary school followed by fathers graduated from college for Urban adolescents.

The highest percentages for the father's job were 78 and $94 \%$ worker fathers of the Urban and Rural group respectively of the study sample. While, for the mother's job was $98 \%$ house wives for the rural group and the percentage was $98 \%$ in urban group as worker.

Also, It could be observed about $94 \%$ of Rural adolescents didn't use any transportation way and $62 \%$ of Urban adolescents used public transportation. Through whole sample ( $80 \%$ and $84 \%$ ) found that no one play any kind of sport for Urban and Rural groups.

There was highly significant difference between two groups $(P<0.001)$. The mean value of father income was (2556 and 1904 LE) for the Urban and Rural groups respectively. Mother's Rural adolescents hadn't any source of income but in Urban group, the mean value of mother's income was 2100 LE. The mean value of other income was (831 and 518 LE.) of Urban and Rural groups respectively with no significant difference between two groups. The mean values of total income for the father's in the two tested groups were 5487 and 2422 LE for Urban and rural sectors respectively with high significant differences. There were significant differences between Urban and Rural groups and pocket money. Rural group had big families, they consist of about 7 members while Urban group had ideal family size about 4 members with highly significant difference $(P<0.001)$. There was no significant difference between two groups for room number and their age. There was highly significant difference between two groups $(P<0.001)$ for hours sleeping, order of adolescent and floor number.

Finally, watching television hours was largely identical in both groups with mean values (4.4 and 4.2 h.) for Urban and Rural groups respectively. In table (6) better-educated parents are more likely to understand disease-prevention measures such as vaccines. They are more likely to take a sick child to a clinic early and to follow treatment instructions. They are more likely to understand germ theory and sanitation and it was found that $78 \%$ of urban adolescent's fathers, $50 \%$ of urban adolescent's mothers had college and secondary certificates although about $64 \%$ of the Rural adolescent's parents were illiterate, or they could read and write, but had no certificate so education had positive effect on nutritional and health status for adolescents. These results are similar to that 


\section{Bassem,A.Zwain}

reported by Quak et al.,(2018) on 5156 adolescents in the slums of Nairobi. As shown in table $(6,7)$ about fathers, mothers jobs, and income,Although there was differences in education levels but job opportunities are similar between the two groups in Egypt. They were working as a worker even if they had college certificate because they didn't equate university degree and the lack of job opportunities so $98 \%$ of mothers were housewives in Rural group. There were significant differences between both income . The same result reported by Martins et al.,(2019) and mentioned that adolescents from poorer households have poor health.

Table (6):

Socio economic characters of parents and physical activity

\begin{tabular}{|c|c|c|c|c|c|}
\hline \multirow{2}{*}{\multicolumn{2}{|c|}{ Variable }} & \multicolumn{2}{|c|}{ Urban group } & \multicolumn{2}{|c|}{ Rural group } \\
\hline & & Frequency & percent & Frequency & percent \\
\hline \multirow{6}{*}{ Education level of father } & College & 18 & $36 \%$ & 3 & $6 \%$ \\
\hline & Secondary & 21 & $42 \%$ & 3 & $6 \%$ \\
\hline & Preparatory & 5 & $10 \%$ & 3 & $6 \%$ \\
\hline & Primary & 3 & $6 \%$ & 6 & $12 \%$ \\
\hline & read \&write & 2 & $4 \%$ & 3 & $6 \%$ \\
\hline & Illiterate & 1 & $2 \%$ & 32 & $64 \%$ \\
\hline \multirow{6}{*}{ Education level of mother } & College & 8 & $16 \%$ & 0 & $0 \%$ \\
\hline & Secondary & 17 & $34 \%$ & 11 & $22 \%$ \\
\hline & Preparatory & 6 & $12 \%$ & 2 & $4 \%$ \\
\hline & Primary & 6 & $12 \%$ & 9 & $18 \%$ \\
\hline & read \&write & 5 & $10 \%$ & 9 & $18 \%$ \\
\hline & Illiterate & 8 & $16 \%$ & 19 & $38 \%$ \\
\hline \multirow{5}{*}{ Father job } & Engineer & 0 & $0 \%$ & 1 & $2 \%$ \\
\hline & free works & 9 & $18 \%$ & 1 & $2 \%$ \\
\hline & Lost & 1 & $2 \%$ & 1 & $2 \%$ \\
\hline & Worker & 39 & $78 \%$ & 47 & $94 \%$ \\
\hline & employee & 1 & $2 \%$ & 0 & $0 \%$ \\
\hline \multirow{2}{*}{ Mother job } & HW & 1 & $2 \%$ & 49 & $98 \%$ \\
\hline & Worker & 49 & $98 \%$ & 1 & $2 \%$ \\
\hline \multirow{3}{*}{ Transportation } & No & 18 & $36 \%$ & 47 & $94 \%$ \\
\hline & on foot & 1 & $2 \%$ & 2 & $4 \%$ \\
\hline & Public & 31 & $62 \%$ & 1 & $2 \%$ \\
\hline \multirow{3}{*}{ Physical activity } & None & 40 & $80 \%$ & 42 & $84 \%$ \\
\hline & Only walking & 5 & $10 \%$ & 6 & $12 \%$ \\
\hline & One physical activity & 5 & $10 \%$ & 2 & $4 \%$ \\
\hline
\end{tabular}


Egypt. J. of Nutrition and Health Vol. 16 No. 1 January (2021)

Table (7):

Socio economic characters of parents (cont.)

\begin{tabular}{l|c|c|c}
\hline Variable & Urban group Mean \pm SD & Rural group Mean \pm SD & T-test \\
\hline Father income & $2556 \pm 44.3$ & $1904 \pm 37.7$ & $7.008^{* * *}$ \\
\hline Mother income & $2100 \pm 24.7$ & 0 & 1 \\
\hline Other income & $831 \pm 14.5$ & $518 \pm 10.5$ & 1.85 \\
\hline Total income & $5487 \pm 13$ & $2422 \pm 24.2$ & $4.38^{* * *}$ \\
\hline Pocket money & $38.6 \pm 20.2$ & $14 \pm 7.4$ & $8.08^{* * *}$ \\
\hline Family member & $4.5 \pm 99$ & $6.6 \pm 1.7$ & $7.49^{* * *}$ \\
\hline Room number & $2.1 \pm 0.48$ & $1.9 \pm 0.45$ & 1.72 \\
\hline Floor number & $4.3 \pm 2.1$ & $2.82 \pm 2.6$ & $7.425^{* \star *}$ \\
\hline Age & $11.4 \pm 9.5$ & $11.8 \pm 8$ & 1.434 \\
\hline Order of Child & $2.5 \pm .99$ & $4.3 \pm 1.8$ & $6.172^{* * *}$ \\
\hline Sleeping hrs & $12 \pm 1.8$ & $10.4 \pm 1.3$ & $5.207^{* * *}$ \\
\hline TV hours & $4.4 \pm 1.1$ & $4.2 \pm 1.7$ & 2.522 \\
\hline
\end{tabular}

The health status for Rural and Urban groups

From the obtained data in table(8), it could be observed that past history of disease for the Urban group (asthma, parasites and gastroenteritis) were (3, 7and 4adolescents cases) respectively and 32 had anemia while 4 adolescents were free from any disease. Concerning the past history of disease among the rural group, There were 32\% adolescents had anemia, $14 \%$ had asthma, 36\% had parasites, $12 \%$ had gastroenteritis , $2 \%$ rickets while $4 \%$ of adolescents were free from any disease. During the period of the study, 25\% of the Urban group did not complain of any disease and $22 \%$ had anemia, whereas $32 \%$ of Rural group had anemia and $24 \%$ were free from any disease. 88 and $42 \%$ of Urban and Rural group respectively had good appetite whereas (12 and 58\%) had bad appetite. As for chewing, it could be observed that the thirty four adolescents reported normal chewing of food and 16 adolescents had bad chewing among the Urban adolescents whereas for Rural group , 23 adolescents reported good chewing of food well and 27 adolescents reported bad chewing. The data in table (8) show comparison between the two groups, no current disease was reported among urban adolescents by $50 \%$ whereas there were $32 \%$ of Rural adolescents had anemia and $18 \%$ had parasites. Total income of Rural adolescent's families was lower than Urban adolescents' families. A large percentage which represented $36 \%$ of Rural adolescents had past history of parasites which was reflected on blood hemoglobin concentration compared with smaller percentage ( $14 \%$ ) of Urban adolescents had past history of parasite. This result was similar to the study demonstrated by(Zimmet et al., 2018) $\mathrm{Hb}$ levels were significantly associated with parasites infection among African school adolescents. 


\section{Bassem,A.Zwain}

Table (8):

Frequency and percent of present and past disease among girls

\begin{tabular}{l|c|c|c|c|c}
\hline \multirow{2}{*}{ Variable } & \multicolumn{2}{c|}{ Urban group } & \multicolumn{2}{c}{ Rural group } \\
\cline { 3 - 6 } \multicolumn{1}{c|}{} & No & 4 & $8 \%$ & 2 & $4 \%$ \\
\cline { 2 - 6 } & Asthma & 3 & $6 \%$ & 7 & $14 \%$ \\
\cline { 2 - 6 } & Anemia & 32 & $64 \%$ & 16 & $32 \%$ \\
\cline { 2 - 6 } & Parasites & 7 & $14 \%$ & 18 & $36 \%$ \\
\cline { 2 - 6 } & gastroenteritis & 4 & $8 \%$ & 6 & $12 \%$ \\
\cline { 2 - 6 } & Rickets & 0 & $0 \%$ & 1 & $2 \%$ \\
\cline { 2 - 6 } & No & 25 & $50 \%$ & 12 & $24 \%$ \\
\cline { 2 - 6 } & Asthma & 3 & $6 \%$ & 7 & $14 \%$ \\
\cline { 2 - 6 } & Anemia & 22 & $44 \%$ & 16 & $32 \%$ \\
\cline { 2 - 6 } & Parasites & 0 & 0 & 9 & $18 \%$ \\
\cline { 2 - 6 } & gastroenteritis & 0 & 0 & 6 & $12 \%$ \\
\cline { 2 - 6 } & rickets & 0 & 0 & 0 & 0 \\
\hline \multirow{4}{*}{ Appetite } & good & 44 & $88 \%$ & 21 & $42 \%$ \\
\cline { 2 - 6 } & loss & 6 & $12 \%$ & 29 & $58 \%$ \\
\hline \multirow{2}{*}{ Chewing } & good & 34 & $68 \%$ & 23 & $46 \%$ \\
\cline { 2 - 6 } & Bad & 16 & $32 \%$ & 27 & $54 \%$ \\
\hline
\end{tabular}

\section{Food Habits for Rural and Urban groups (Table 9)}

The tlle shows that 45 child were washing their hand before meals who represent $90 \%$ of the Urban group but, in the other group, it was $48 \%$ of the Rural group adolescents who washed their hands before meals. All adolescents' mother washed fruits and vegetables before providing it to their children but $28 \%$ of adolescents which belong to Rural group, they let their children eating fruit and vegetables without washing. As for exposure to sunlight it could be observed that (94 and 26\%) of Urban and Rural group respectively exposed to sunlight, whereas (6 and 74\%) they were not exposed to sunlight. The majority of both groups ate during watching TV (84 and 92\%) for Urban and Rural groups.For the number of eating meals , 68 and $56 \%$ of Urban and Rural groups used to eat more than 4 meals.

Most of Urban and Rural groups preferred mesabek's cooking way, while the high percentage for Rural group after mesabk method was fried method. 82 and $76 \%$ of the Urban and Rural adolescents respectively were drinking enough water, whereas (18 and 24\%) of the Urban and Rural adolescents respectively were drinking a little water. Concerning eating snacks (carbonate, juice, other and tea) were (21, 16, 3 and 10) adolescents respectively from the Urban group, whereas taking snacks of the Rurala dolescents were (carbonate, juice, other and tea) were (27, 10,3 and 10) adolescents. As for pickles, it could be observed that 9 adolescents from Urban group and 30 adolescents from Rural group used to eat food with pickles while 41 adolescents from Urban group and 20 adolescents from Rural group used to eat food without pickles. $28 \%$ and $52 \%$ of Rural adolescents didn't wash fruit, vegetable and their hands respectively before meals which might result in lead poisoning and anemia, similar result said that low-income adolescents are routinely screened for anemia and elevated blood lead levels (Bereson et al., 2017). 
Egypt. J. of Nutrition and Health Vol. 16 No. 1 January (2021)

Table (9):

Frequency and percent of food habits and hygienic behaviours of Rural and Urban groups.

\begin{tabular}{|c|c|c|c|c|c|}
\hline \multirow{2}{*}{\multicolumn{2}{|c|}{ Variable }} & \multicolumn{2}{|c|}{ Urban group } & \multicolumn{2}{|c|}{ Rural group } \\
\hline & & \multirow{2}{*}{$\begin{array}{c}\text { Frequency } \\
45\end{array}$} & \multirow{2}{*}{$\begin{array}{c}\text { Percent } \\
90 \%\end{array}$} & \multirow{2}{*}{$\begin{array}{c}\text { Frequency } \\
24\end{array}$} & \multirow{2}{*}{$\begin{array}{c}\text { Percent } \\
48 \%\end{array}$} \\
\hline Wrach hands & yes & & & & \\
\hline vvasitilamus & no & 5 & $10 \%$ & 26 & $52 \%$ \\
\hline \multirow{2}{*}{ Wash fruit and vegetables } & yes & 50 & $100 \%$ & 36 & $72 \%$ \\
\hline & no & 0 & $0 \%$ & 14 & $28 \%$ \\
\hline \multirow{2}{*}{ Exposure to sun } & yes & 47 & $94 \%$ & 13 & $26 \%$ \\
\hline & no & 3 & $6 \%$ & 37 & $74 \%$ \\
\hline \multirow{2}{*}{ Eating during TV watch } & yes & 42 & $84 \%$ & 46 & $92 \%$ \\
\hline & no & 8 & $16 \%$ & 4 & $8 \%$ \\
\hline \multirow{3}{*}{ Number of meals a day } & 3 & 4 & $8 \%$ & 10 & $20 \%$ \\
\hline & 4 & 12 & $24 \%$ & 12 & $24 \%$ \\
\hline & More than 4 & 34 & $68 \%$ & 28 & $56 \%$ \\
\hline \multirow{4}{*}{ Cooking way } & Mesabek & 32 & $64 \%$ & 28 & $56 \%$ \\
\hline & Fried & 14 & $28 \%$ & 22 & $44 \%$ \\
\hline & Grill & 4 & $8 \%$ & 0 & 0 \\
\hline & Boiled & 0 & 0 & 0 & 0 \\
\hline \multirow{2}{*}{ Water during meal } & yes & 41 & $82 \%$ & 38 & $76 \%$ \\
\hline & no & 9 & $18 \%$ & 12 & $24 \%$ \\
\hline \multirow{4}{*}{ Snacks\& drinks } & $\begin{array}{c}\text { Carbonate } \\
\text { Soda }\end{array}$ & 21 & $42 \%$ & 27 & $54 \%$ \\
\hline & juice & 16 & $32 \%$ & 10 & $20 \%$ \\
\hline & other & 10 & $20 \%$ & 3 & $6 \%$ \\
\hline & tea & 3 & $6 \%$ & 10 & $20 \%$ \\
\hline \multirow{2}{*}{ Pickles } & yes & 9 & $18 \%$ & 30 & $60 \%$ \\
\hline & no & 41 & $82 \%$ & 20 & $40 \%$ \\
\hline
\end{tabular}

\section{Conclusion}

From the obtained results, It could be concluded that anthropometric measurements and nutrients intakes of rural adolescents were worst than the urban adolescents, the most common disease among Rural group were parasites and anemia. The intake of protein and fat, for rural adolescents were less than urban adolescents. Finally, the attention must be paid to introduce balanced diet, fortified food for these adolescents and teach families to improve dietary and health behavior. 


\section{References}

Bereson, G.S.; Srinivasan, S.R.; Bao, W.; Newman, W.P.; Tracy, R.E. and Wattigney, W.A.(2017): Association between multiple cardiovascular risk factors and atherosclerosis in children and young adults. The Bogalusa Heart Study. N. Eng. J. M., 338:1650-6.

Binns, H.J. and Ariza, A.J.(2004):

Guidelines help clinicians identify risk factors for overweight in children. Pediatric Arch.,33:1822.

Carmo, I.; dos Santos, O.; Camolas, J.; Vieira, J.; Carreira, M. and Medina, L. (2013):

Overweight and obesity in Portugal: National prevalence in 2010-2012. Obes. Ver., 9:11-9.

Dacie, A. D. and Lewis, J. (1998):

Practical Hematology Churchill Livingston. 11th Ed., New York.

Fernandez, J.R.; Redder, D.T.; Pietrobelli, A. and Allison, D.B.(2004):

Waist circumference percentile in national representative sample of African-American, European. J. Pediatric, 145:439-44.

\section{FIAS(1996):}

Food Intake Analysis System Manager Manual, University of Texas Version 2.0, Health Science Center at Houston, Center service, HoustinTaxas USA.

Fraser, D.; Jones, G.; Kooh, S. W. and Radde, I. C. (1986):

Calcium and phosphate metabolism, in : Textbook of Clinical Chemistry, Tiez, N. W. Ed. Saunders, Philadephia, USA.

Frisancho, A.R.(1990):

Anthropometric standards for the assessment of growth and nutritional status. Ann Arbor: University of Michigan Press, Appendix B, C.

I.F.C.C. (1983):

Methods for the measurement of catalytic concentration of enzymes - Part 5: IFCC, methods for alkaline phosphatase. J. Clin. Chem. Clin. Biochem.,21:731-748.

Jolliffe, C.J. and Janssen, I.(2018):

Vascular risk and management of obesity in children and adolescents. Vasc. Health Risk Manag., 2:71-87

Levin, K.A.(2014):

Urban-rural differences in adolescent eating behavior: A multilevel cross-sectional study of 15years-olds in Scotland. Public Health Nutr., 17:1776-85. 


\section{Egypt. J. of Nutrition and Health Vol. 16 No. 1 January (2021)}

Lobstein, T.; Baur, L. and Uauy, R.(2004):

For the International Association for the study of obesity of the international obesity task force. Obesity in children and young people: A crisis in public health. Obes. Rev., 5 (1):4-104.

Makarem, A.(1974):

Hemoglobin, myoglobin and hebatoglobin Clinical chemistry: Principles and techniques, 1111-1214.

Martins, D.; Tareen, N.; Pan, D. and Norris, K.(2019):

The relationship between body mass index and pulse pressure in older adults with isolated systolic hypertension. Am. J. Hypertens., 15:538-432.

Ohly, H.R.; Hayter, A.; Pettinger, C.; Pikhart, H.; Watt, R.G. and Rees, G.A.(2013):

Developing a nutrition intervention in children's centres: Exploring views of parents in rural/urban environments in the UK. Public Health Nutr., 16:1516-21.

Passmore, R. and Eastwood, M.A. (1986):

Human Nutrition and Dietetics, 8th Ed, Churchill.

Picciano, M.F. (2017):

Estimation of total usual calcium and vitamin D intakes in the United States. J. Nutr. 140(4):817-22.

Quak, S.H.; Furnes, R.; Lavine, J. and Baur, L.(2018):

Obesity Working Group. Obesity in children and adolescents. J. Ped. Gastr.Nutr., 47:254-9.

Snedecor, W.G,Cochran(1972):

Biometrics Buy Statistical Methods. Sixth Edition.

Troiano, R.P. and Flegal, K.M.(2019):

Overweight children and adolescents: Description, epidemiology and demographics. Pediatrics, 101:497-504.

(WHO) World Health Organization 1998):

Obesity: Prevention and managing the global epidemic: Report of a WHO consultation on obesity Geneva.

Zimmet, P.; Alberti, G.; Kaufman, F.; Tajima, N.; Silink, M, and Arslania, S. (2018):

The metabolic syndrome in children and adolescents: The IDF consensos. Diabetes Voice, 52(4):29-32. 


\section{Bassem,A.Zwain}

\section{دراسة العوامل المرتبطة بزيادة الوزن والسمنة للبنات في سن المراهقة المبكرة في المناطق الحضرية والريفية والرية \\ باسم على زوين}

زميل التفذية العلاجية ـ مستثفيات جامعة القاهرة

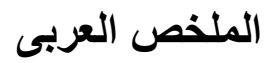

السمنة مشكلة معقدة ناتجة عن عدم التوازن بين تتاول و إنفاق الطاقة مع المكونات الجينية والايضيةو السلوكية.

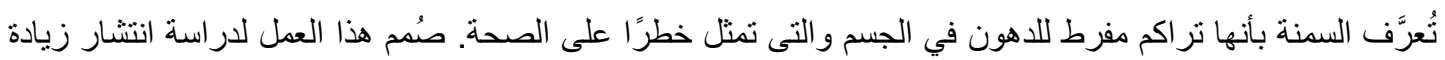

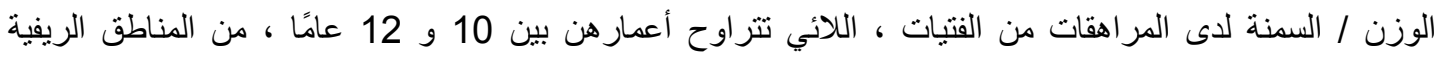

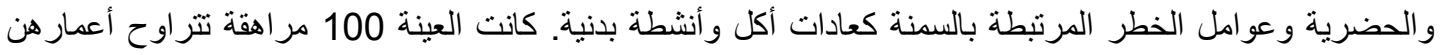

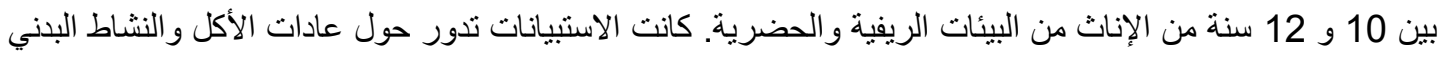

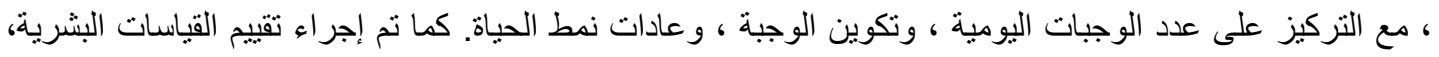

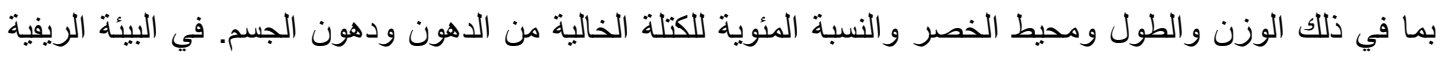

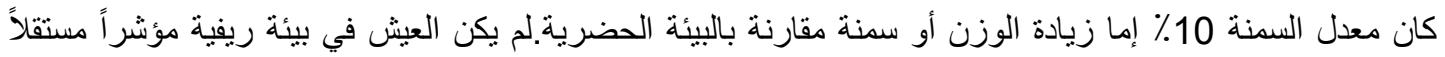

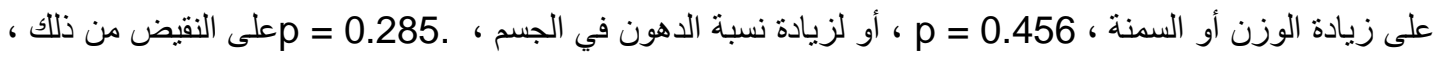

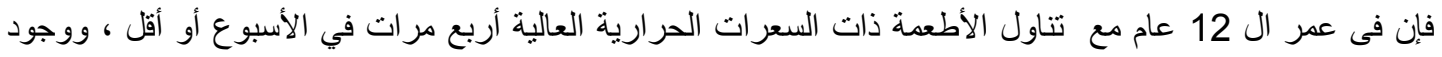

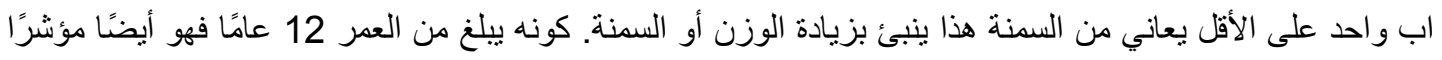
على اكتساب دهون متوسطة إلى عالية في الجسم.

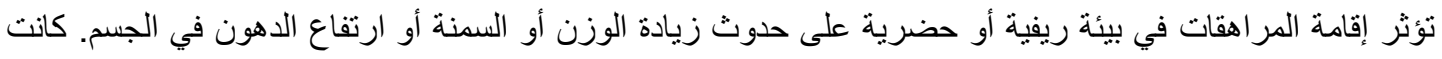

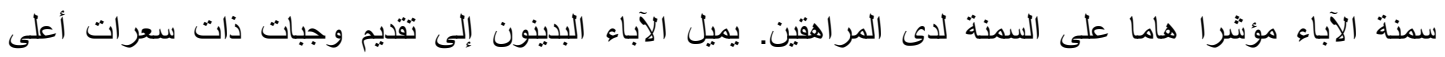
للمر اهقين.

الكلمات المفتاحية: الريف والحضر - تقييم القياسات البشرية- عادات نمط الحياة ـ المر اهقون البدينون في وقت مبكر 